\title{
Atmospheric processes triggering the central European floods in June 2013
}

\author{
C. M. Grams, H. Binder, S. Pfahl, N. Piaget, and H. Wernli \\ Institute for Atmospheric and Climate Science, ETH Zurich, Switzerland \\ Correspondence to: C. M. Grams (christian.grams@env.ethz.ch)
}

Received: 5 December 2013 - Published in Nat. Hazards Earth Syst. Sci. Discuss.: 20 January 2014

Revised: 12 May 2014 - Accepted: 23 May 2014 - Published: 4 July 2014

\begin{abstract}
In June 2013, central Europe was hit by a century flood affecting the Danube and Elbe catchments after a 4 day period of heavy precipitation and causing severe human and economic loss. In this study model analysis and observational data are investigated to reveal the key atmospheric processes that caused the heavy precipitation event. The period preceding the flood was characterised by a weather regime associated with cool and unusual wet conditions resulting from repeated Rossby wave breaking (RWB). During the event a single RWB established a reversed baroclinicity in the low to mid-troposphere in central Europe with cool air trapped over the Alps and warmer air to the north. The upperlevel cut-off resulting from the RWB instigated three consecutive cyclones in eastern Europe that unusually tracked westward during the days of heavy precipitation. Continuous large-scale slantwise ascent in so-called "equatorward ascending" warm conveyor belts (WCBs) associated with these cyclones is found as the key process that caused the 4 day heavy precipitation period. Fed by moisture sources from continental evapotranspiration, these WCBs unusually ascended equatorward along the southward sloping moist isentropes. Although "equatorward ascending" WCBs are climatologically rare events, they have great potential for causing high impact weather.
\end{abstract}

\section{Introduction}

A very severe heavy precipitation and flooding event hit central Europe at the end of May and beginning of June 2013. All catchments on the Alpine north-side (Switzerland, Austria, and southern Germany) and of the mountain ranges in southern and eastern Germany as well as in the Czech Re- public were affected. While the more western Rhine catchment experienced flooding only locally, very severe flooding occurred over large areas of the Danube and Elbe catchments. Stream gauge observations along the Danube, Elbe, and their tributary rivers exceeded 100 year levels at many locations (e.g. LfU, 2013). The event caused at least 25 fatalities and produced an estimated economic damage of more than EUR 12 billion with most of the damage in Germany and Austria (Munich RE, 2013).

Major large-scale flooding events result from the interaction of atmospheric and hydrological processes. Often the area affected experiences prolonged wet conditions prior to a major flooding event so that soils are already saturated and river discharge is high. The quasi-stationarity of such a preceding large-scale flow situation leading to wet conditions in the catchment indicates that a so-called "weather regime" (e.g. Vautard, 1990) may be involved. Thereafter, an approx. 2 day heavy precipitation event triggers the flooding. Extreme precipitation in Europe is often closely linked to upper-level precursors (e.g. Massacand et al., 1998), the presence of surface cyclones (e.g. Pfahl and Wernli, 2012b) and the long-range transport of moisture (e.g. Stohl and James, 2004). To improve our ability to predict such floods it is important to investigate the key meteorological processes that govern a flooding event, in particular the dynamics of the cyclones and upper-level flow features involved, their track, and the sources and transport of moisture. In the following we give a brief overview on these topics focusing on central Europe.

In recent years the Danube and Elbe region experienced several flooding events with similarly severe impacts. For instance, century floods occurred in 1997 in the more northeastern Oder catchment (Keil et al., 1999), in 2002 in the 
Elbe and Danube catchments (Ulbrich et al., 2003a, b; James et al., 2004; Sodemann et al., 2009), and in 2005 again in the catchments of Danube and the Swiss Rhine tributary Aare (Zängl, 2007a, b; Hohenegger et al., 2008). All these recent floods happened in the summer and their meteorological setting involved extratropical cyclones of type "Vb", which refers to a special category of cyclone tracks in Europe (van Bebber, 1891). These cyclones form south of the Alps and track north-eastward around the Alps into eastern Europe and the Baltic Sea. Due to their origin in the Mediterranean they often bring very moist and warm air around the Alps and lead to heavy precipitation over central and eastern Europe. The northerly flow to the west of "Vb" cyclones favours orographic enhancement of precipitation along the west-east oriented mountain ranges of central and eastern Europe as well as along the Alpine north-side. Pfahl and Wernli (2012b) documented the high relevance of cyclones for extreme precipitation from a more general, climatological perspective. They also showed that cyclones causing heavy precipitation are not necessarily extreme in terms of their cyclone properties, like for instance the minimum sea level pressure.

An important fraction of large-scale precipitation in extratropical cyclones occurs in the warm sector ahead of the cold front where air ascends poleward along the sloped isentropes within so-called warm conveyor belts (WCBs, Browning et al., 1973; Browning, 1990; Madonna et al., 2014). For central Europe, Pfahl et al. (2014) quantified that 20-40\% of all extreme precipitation events during 1979-2010 were linked to WCBs and even 40-60\% either to a WCB or a cyclone. James et al. (2004) and Stohl and James (2004) documented that during the 2002 Elbe flooding event, evaporative moisture sources were initially located in the Mediterranean and later over land in eastern Europe and the Black Sea. Winschall (2013) investigated several European flooding events in detail and found a high case-to-case variability of the moisture source regions. Finally, Sodemann and Zubler (2010) reported an important seasonal shift in the moisture source of Alpine precipitation. In winter the moisture evaporates mainly from oceanic regions (Mediterranean, North Atlantic), whereas in summer continental moisture sources become more relevant (see their Figs. 2 and 4).

In this study we investigate the atmospheric processes leading to the central European floods in June 2013. After a brief description of the data and methods (Sect. 2), we explore the weather characteristics in Europe during the weeks prior to the event (Sect. 3) and investigate whether and how a weather regime preconditioned the region for flooding. In Sect. 4 a detailed overview on the synoptic situation during the heavy precipitation event is given. A potential vorticity (PV) perspective is adopted (Hoskins et al., 1985), which is very useful for studying cyclone dynamics and the effect of latent heating (e.g. in WCBs) on the diabatic PV modification in the lower and upper troposphere (e.g. Grams et al., 2011). Thereby we investigate the role of the tracks and dynamics of the involved cyclones, the moisture sources, and the con- tribution of precipitation from warm conveyor belts. We also address the question whether the heavy precipitation event went along with a weather regime transition. Since we identify a particular type of warm conveyor belt, we focus then on this particular category of airstreams in Sect. 5. Finally, we conclude and discuss our key findings (Sect. 6).

\section{Data and methods}

\subsection{Data}

The high-resolution operational analyses (HRES) of the European Centre for Medium Range Weather Forecast (ECMWF) integrated forecast system are used as the data basis for this study, interpolated on a geographical grid with $0.25^{\circ}$ spatial resolution every six hours. Data from the ECMWF's ERA-Interim reanalysis (Dee et al., 2011) at $1.0^{\circ}$ horizontal and 6-hourly temporal resolution are used for climatological investigations.

The spatial distribution of precipitation is estimated with the gridded daily precipitation product with $1.0^{\circ}$ spatial resolution from the Global Precipitation Climatology Centre (GPCC) (Schamm et al., 2014). GPCC's precipitation climatology (Schneider et al., 2014) is used as a reference. GPCC data strongly underestimate local extremes but they represent well the large-scale precipitation patterns. Therefore, selected precipitation measurements from station data serve to highlight local extremes. The cloud signature of WCBs is discussed with satellite data from the SEVIRI instrument on the Meteosat Second Generation satellite (MSG) in the visible $(0.56-0.71 \mu \mathrm{m}$ wave length) spectral band.

\subsection{Blocking and cut-off identification}

To investigate the role of weather regimes, atmospheric blocking is identified with a diagnostic developed by Schwierz et al. (2004), which was also used by, e.g. CrociMaspoli et al. (2007) and Pfahl and Wernli (2012a). Negative anomalies (i.e. deviations from climatology) of uppertropospheric potential vorticity (averaged between 500 and $150 \mathrm{hPa}$ ) are tracked over consecutive time steps. If such anomalies persist for more than 5 days, they are identified as blocking. As in Pfahl and Wernli (2012a), for taking also weaker blocking into account, a threshold value of $-0.7 \mathrm{PVU}$ is chosen for the detection of PV anomalies - in contrast to the more restrictive threshold of $-1.3 \mathrm{PVU}$ used by CrociMaspoli et al. (2007).

For climatological considerations stratospheric PV cutoffs on isentropic surfaces are determined using ERAInterim data and the method introduced by Wernli and Sprenger (2007). To account for seasonal variability, we consider a grid point to exhibit an upper-level cut-off if the diagnostic determines a stratospheric PV cut-off at least on one level between 305 and $330 \mathrm{~K}$ (every $5 \mathrm{~K}$ ). 


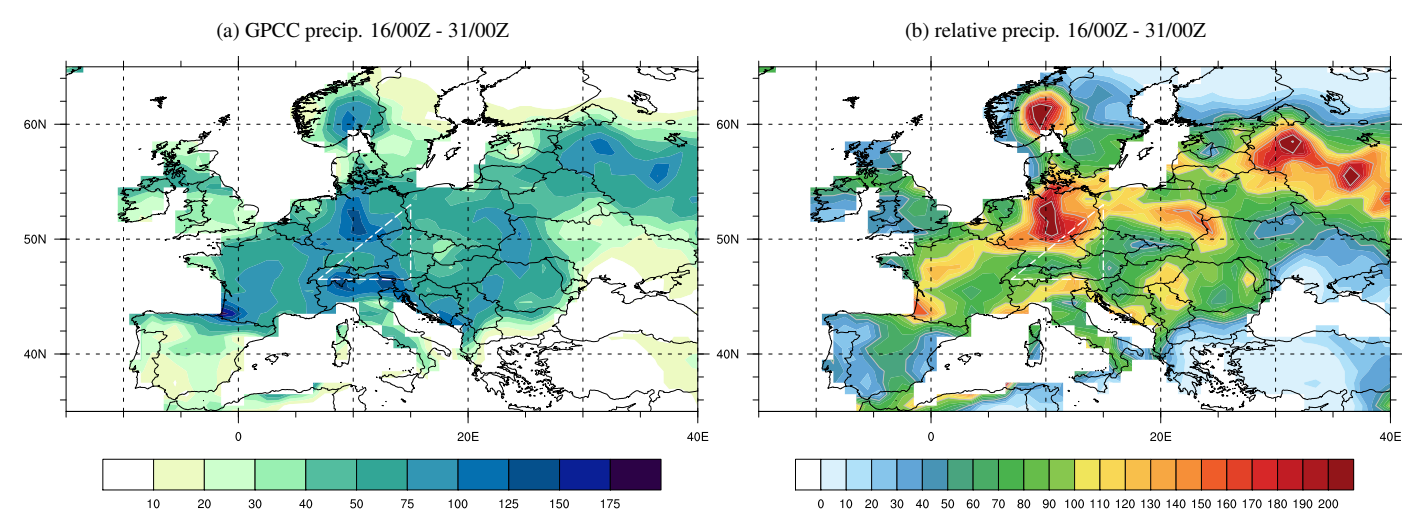

Figure 1. (a): observed precipitation over land (shaded in mm) from first guess GPCC data accumulated from 16 May 2013, 00:00 UTC to 31 May 2013, 00:00 UTC and (b): fraction of total climatological May precipitation that fell during this 15 day period (shaded every $10 \%$, blue $<50 \%$, green $50-100 \%$, yellow $100-150 \%$, red $>150 \%$ ).

\subsection{Moisture source diagnostics}

Evaporative moisture sources of the precipitation event are calculated with the Lagrangian technique developed by Sodemann et al. (2008). This technique considers 6-hourly changes of specific humidity $q$ along backward trajectories from the considered area of precipitation and attributes positive changes of $q$ with time to local moisture uptake due to surface evaporation. More specifically, this approach involves the following steps: (1) 10 day kinematic backward trajectories are calculated with the tool LAGRANTO (Wernli and Davies, 1997), every $6 \mathrm{~h}$ during the period of intense precipitation using the $0.25^{\circ}$ ECMWF analysis data on all model levels. The trajectories are calculated from all points of a regular grid where relative humidity exceeds $80 \%$. This threshold is used to focus on air parcels that likely produce precipitation in the target area. The regular grid has a spacing of $20 \mathrm{~km}$ in the horizontal and $30 \mathrm{hPa}$ in the vertical and covers a box that includes the heavy precipitation event $\left(7-16^{\circ} \mathrm{E}\right.$, $46-52^{\circ} \mathrm{N}$, see red box in Fig. 4) and extends in the vertical from 1000 to $500 \mathrm{hPa}$. (2) Specific humidity $q$ is traced along these backward trajectories, and all 6-hourly intervals are identified during which $q$ is increasing with time. The positive change $(\Delta q)$ relative to the total specific humidity of the air parcel indicates the intensity of the moisture uptake event at the diagnosed location and time. (3) For every trajectory starting time, the identified moisture uptake events are weighted and aggregated to get the overall moisture uptake distribution for the precipitation in the target area at this particular time. Weighting of the individual moisture uptakes is necessary since precipitation (negative 6-hourly $\Delta q$ ) can occur along trajectories between the uptake and the arrival in the target area. The intensity of these uptakes preceding the precipitation is reduced since they contribute less to the moisture arriving in the area of interest. This procedure is explained in detail in Sodemann et al. (2008), and has been applied successfully in several previous studies, for example, Sodemann and Zubler (2010), Winschall et al. (2012, 2014).

\subsection{WCB diagnostics}

Again, trajectories calculated with LAGRANTO are used to detect WCBs for a sequence of 6-hourly shifted 2 day time periods. Following Wernli and Davies (1997), trajectories with the strongest ascent $(>600 \mathrm{hPa}$ ) in $48 \mathrm{~h}$ are selected and considered as WCB trajectories. As previously introduced by Grams et al. (2011), their intersection points with an isentropic surface reveal the impact of the WCB outflow on the upper-level mid-latitude flow. Regions where precipitation is related to WCBs are determined following the method introduced by Pfahl et al. (2014). If moisture decreases by more than $1 \mathrm{~g} \mathrm{~kg}^{-1}$ within $6 \mathrm{~h}$ along a WCB trajectory, all surrounding grid points are marked, and surface precipitation at these locations is associated with the WCB. We also use the ERA-Interim based WCB climatology of Madonna et al. (2014) for climatological considerations.

\section{Preconditioning by quasi-stationary flow features}

Unusual cool and wet conditions characterised the weather in and around central Europe during May 2013. In the two weeks prior to the flood event, high accumulated GPCC precipitation of more than $75 \mathrm{~mm}$ in 15 days occurred in many regions, in particular those affected by severe flooding in early June (Fig. 1a). In the western Czech Republic and in central and northern Germany more than $100 \%$ of the climatological May precipitation fell during these 15 days (Fig. 1b). In southern Germany and the northern Alps, precipitation amounts reached 50-100\% of the usual May precipitation. Thus in most regions affected by flooding later, soils were potentially saturated and river runoff was at a high level (e.g. LfU, 2013). 


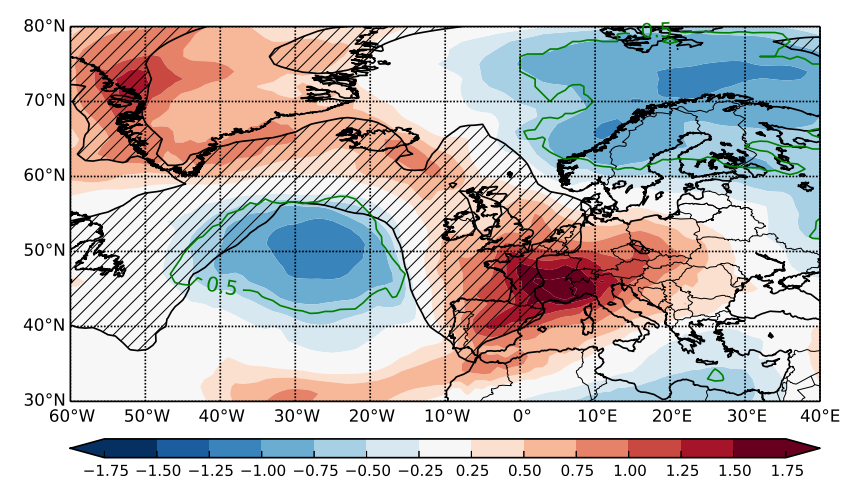

Figure 2. Anomaly of vertically averaged (500-150hPa) PV calculated as the deviation of the time averaged field between 16 May 2013, 00:00 UTC and 31 May 2013, 00:00 UTC from the 1979 to 2010 ERA-Interim May climatology (shaded every $0.25 \mathrm{PVU}$ ). The hatching shows the regions with standard deviation of the 6-hourly PV-anomalies during these 15 days exceeding $0.75 \mathrm{PVU}$, and the green contour the region with blocking frequency larger than $50 \%$ during the same period.

The cool and wet conditions were caused by repeated upper-tropospheric Rossby wave breaking (RWB) and the consequent occurrence of a quasi-stationary upper-level cutoff low over Europe. This is reflected by a strong timeaveraged positive upper-level PV anomaly centred over the western Alps during 16-31 May 2013 (Fig. 2). High values for the standard deviation of vertically integrated upperlevel PV over the eastern North Atlantic and over the British Isles reflect the repeated RWB (hatched region in Fig. 2), while lower values over central Europe indicate the quasistationarity and persistence of the upper-level cut-off low. The RWB occurred at the downstream side of a quasistationary anticyclone in the central North Atlantic reflected by a strongly negative PV anomaly and low standard deviation. A quasi-stationary anticyclone also occurred over Scandinavia north-east of the RWB. For both the Atlantic and Scandinavian anticyclones, the objective blocking diagnostic indicates more than $50 \%$ of blocked days in the two-week period prior to the heavy precipitation event (green contour in Fig. 2).

In terms of the four classical European weather regimes (e.g. Vautard, 1990), this large-scale flow configuration in the Atlantic European region can be regarded as a hybrid of the Atlantic and Scandinavian blocking regime or a transition between them. In recent years the dynamical link between RWB and blocking regimes has been studied by various authors (e.g. Croci-Maspoli et al., 2007; Altenhoff et al., 2008; Michel and Rivière, 2011; Michel et al., 2012). These studies revealed increased frequencies of RWB during the onset, decay or transition of blocking regimes, and concluded that RWB is a crucial factor in a blocking regime's life cycle.

\section{Synoptic evolution during the heavy precipitation event}

\subsection{Precipitation, cyclone tracks, and moisture sources}

Here we focus on the core period of the heavy precipitation event from 31 May 2013, 00:00 UTC to 3 June 2013, 00:00 UTC. During this period the $72 \mathrm{~h}$ accumulated precipitation exceeds $50 \mathrm{~mm}$ in a region extending from eastern Switzerland, the Austrian Alps, southern and eastern Germany, to the Czech Republic (Fig. 3a, outlined by triangle). North of the Alps, the $72 \mathrm{~h}$ precipitation exceeds even $100 \mathrm{~mm}$ and also the Erzgebirge shows a local maximum of more than $75 \mathrm{~mm}$ near $12.5^{\circ} \mathrm{E}, 50.5^{\circ} \mathrm{N}$. In a large area, $50 \%$ of the climatological May precipitation fell during the 3 day core period and more than $100 \%$ over the northern slopes of the Alps and the western Czech Republic (Fig. 3b). Recalling that this is a coarse $\left(1^{\circ}\right)$ gridded data set, these numbers are alarming. Much higher rainfall amounts were actually recorded at individual stations, for example, AschauStein in the Danube catchment observed more than $400 \mathrm{~mm}$ from 30 May to 3 June or Stützengrün-Hundshübel in the Elbe catchment more than $200 \mathrm{~mm}$ during the same period (e.g. LfU, 2013).

The precipitation was linked to the subsequent passage of three cyclones - "Dominik", "Frederik", and "Günther" (see tracks in Fig. 3b). These cyclones formed over (south-) eastern Europe ahead of short-wave troughs that travelled around the quasi-stationary upper-level cut-off (as discussed below). All these cyclones unusually tracked westward and maintained a northerly flow against the west-east oriented mountain ranges in central Europe. The first cyclone, "Dominik", moved north of the heavy precipitation region and reached a minimum sea level pressure (mslp) of $997 \mathrm{hPa}$ on 28 May 2013, 06:00 UTC. It decayed just before the onset of intense precipitation and was followed by "Frederik". This second cyclone was probably the most essential of the three cyclones for the precipitation event. It reached a mslp of $996 \mathrm{hPa}$ on 30 May 2013, 18:00 UTC, and crossed the heavy precipitation region on 31 May and 1 June 2013. Finally "Günther" approached the heavy precipitation region from the east during 1 and 2 June 2013. It reached a mslp of $998 \mathrm{hPa}$ on 1 June 2013, 06:00 UTC. It is striking that all three cyclones are rather shallow systems with relatively high values of mslp, and that they occur as a "cluster" with very similar tracks.

The moisture source diagnostic computed for the precipitation that occurred in the region $7-16^{\circ} \mathrm{E}, 46-52^{\circ} \mathrm{N}$ from 31 May 2013, 00:00 UTC to 3 June 2013, 00:00 UTC (Fig. 4) indicates that most of the moisture evaporated over land in central and eastern Europe. The source region agrees remarkably well with the region that received more than $100 \%$ of climatological May precipitation during the two weeks prior to the heavy precipitation event (cf. Fig. 1b). The moisture source region also coincides with the track of cyclone 
(a) 3 day precipitation $31 / 00 Z-03 / 00 Z$

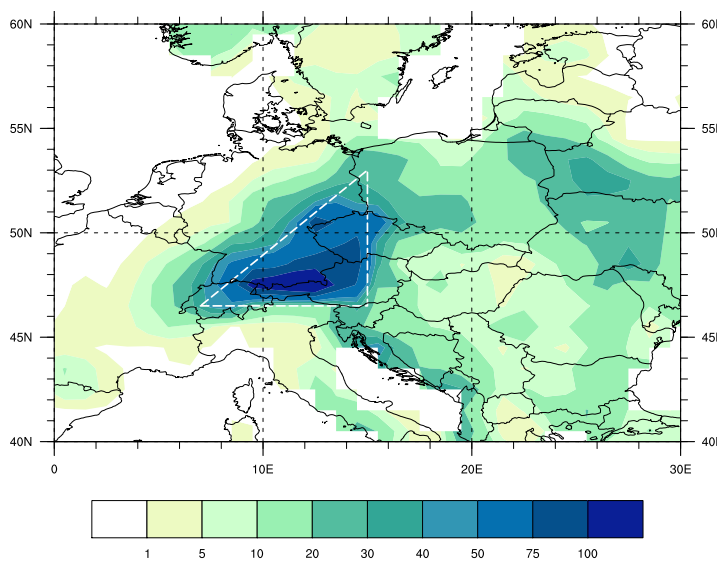

(b) 3 day relative precipitation

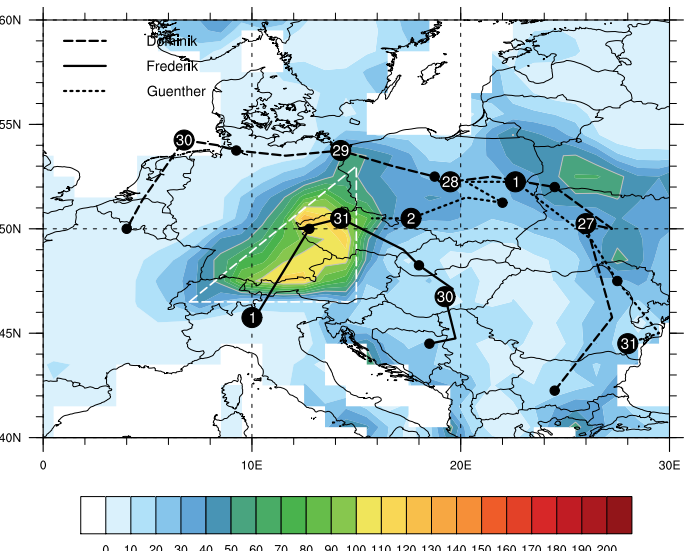

Figure 3. (a): GPCC precipitation accumulated over the 3 day core period of the heavy precipitation event from 31 May 2013, 00:00 UTC to 3 June 2013, 00:00 UTC. (b): fraction of total climatological May precipitation that fell in this 3 day period (shaded every $10 \%$, as Fig. 1 b) and tracks of the three consecutive cyclones (long-dashed: Dominik, solid: Frederik, short-dashed: Günther; derived from ECMWF analysis data) with 00:00 UTC labelled by day of May/June 2013 and small dots for 12:00 UTC positions. The white triangle highlights the core region affected by heavy precipitation.

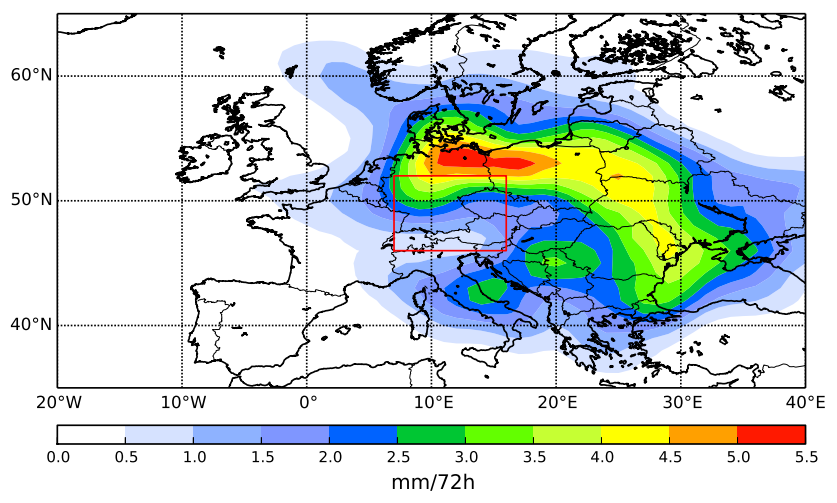

Figure 4. Evaporative moisture sources for precipitation in the red box during the 3 day core period of the heavy precipitation event from 31 May 2013, 00:00 UTC to 3 June 2013, 00:00 UTC (shading, showing moisture uptake in $\mathrm{mm} / 72 \mathrm{~h}$ ).

"Dominik" (cf. Fig. 3b) that occurred just prior to the heavy precipitation event and initiated the heavy precipitation period in central Europe on 30 May 2013. This suggests that the availability of moisture over land along the track of the three consecutive cyclones was crucial for the very high rainfall amounts in central Europe. It is surprising that comparatively few moisture uptakes are diagnosed over oceans, with only minor contributions from the Adriatic Sea, the Black Sea, and the Baltic Sea.

Similarly, for an eastern European flood event in May 2010, Winschall et al. (2014) found continental moisture sources to be crucial for the heavy precipitation in addition to important moisture sources in the North Atlantic and Mediterranean. Also James et al. (2004) stressed the importance of continental moisture sources for the 2002 Elbe flood, although this event was characterised by a variety of moisture sources (Sodemann et al., 2009).

\subsection{Detailed synoptic evolution and cyclone dynamics}

In the following the synoptic evolution during the core period of the heavy precipitation event is described with a daily sequence of PV charts on $320 \mathrm{~K}$, sea level pressure (slp), and visible satellite imagery from 31 May 2013, 12:00 UTC to 3 June 2013, 12:00 UTC (Fig. 5). The $320 \mathrm{~K}$ isentropic surface is particularly suited to investigate the upper-tropospheric flow between 500 and $300 \mathrm{hPa}$. A strong PV gradient centred around the $2 \mathrm{PVU}$ contour reflects the location of the mid-latitude Rossby wave guide and of the mid-latitude jet. We also indicate regions where a blocking anticyclone was objectively identified (blue contours in left panels of Fig. 5). At selected times, intersection points of WCB trajectories with the isentropic layer $320 \mathrm{~K} \pm 2.5 \mathrm{~K}$ help to assess the impact of WCB outflows on the upper-level flow. In addition, thick clouds in the visible satellite imagery reflect the ascent region of WCBs in the lower and middle troposphere. The objectively identified regions where WCBs cause precipitation are marked by green contours in the right panels of Fig. 5.

On 31 May 2013, 12:00 UTC, the upper-level flow shows the quasi-stationary flow pattern that also characterised the previous two weeks (Fig. 5a, compare with Fig. 1b). A cyclonic RWB is reflected by high positive PV at $320 \mathrm{~K}$ over Europe and the Mediterranean forming a major upperlevel cut-off low. Upstream it is accompanied by an eastern North Atlantic blocking anticyclone centred at $25^{\circ} \mathrm{W}, 43^{\circ} \mathrm{N}$. Downstream and north of the cut-off, a major Scandinavian blocking anticyclone is evident. The centre of "Frederik" 

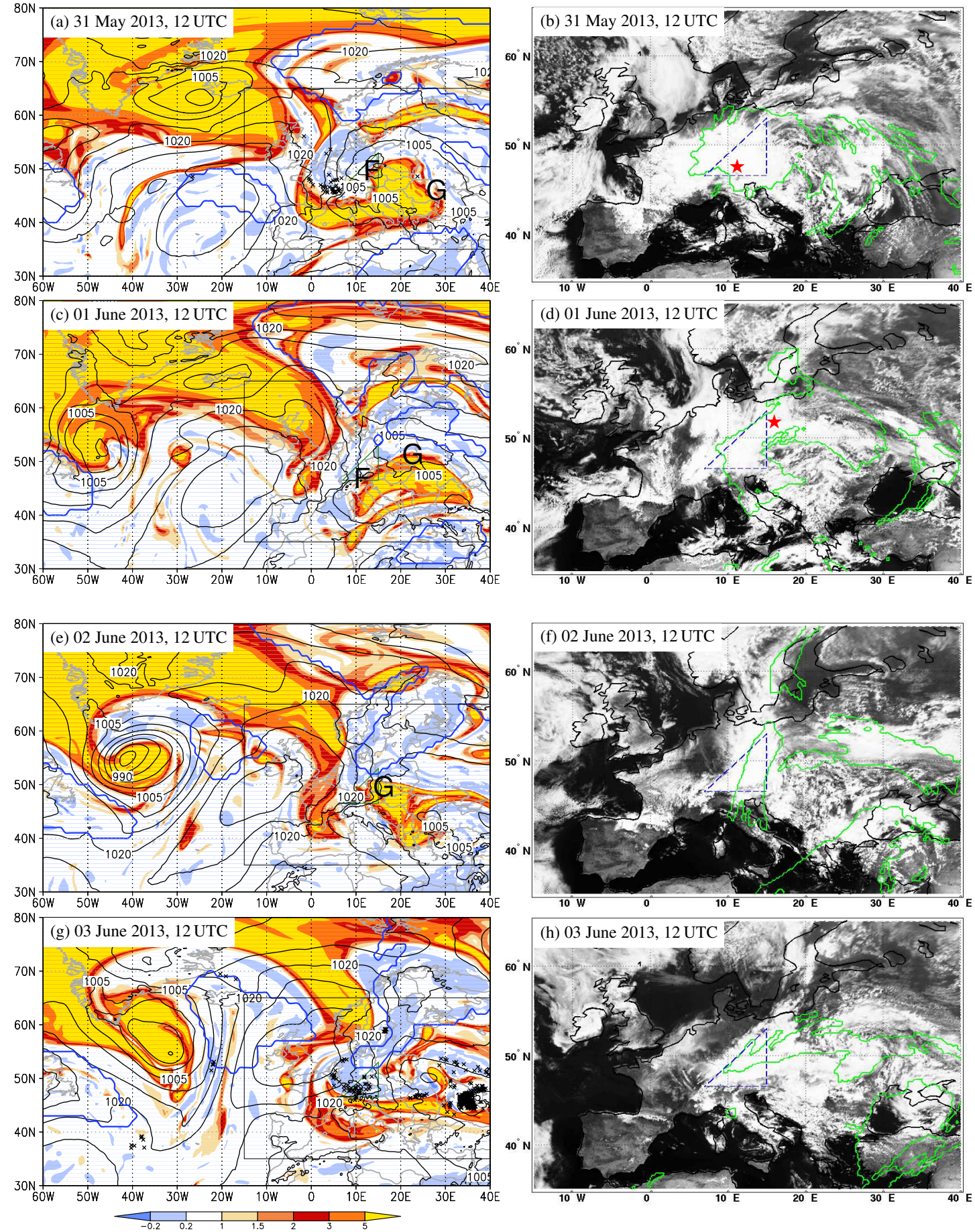

Figure 5. Left: PV at $320 \mathrm{~K}$ (shaded in PVU), mean sea level pressure (black every $5 \mathrm{hPa}$ ), outline of identified blockings (blue contour), and in (a-g) every 10th WCB trajectory intersection point with the layer $320 \mathrm{~K} \pm 2.5 \mathrm{~K}$. Only these WCBs are considered that contribute to the flooding event. The labels F and G mark the position of Frederik and Günther, respectively. Right: MSG-SEVIRI VIS 0.56-0.71 $\mu$ m satellite imagery zoomed over Europe (see box in left panels) and regions with precipitation from WCBs during the last $24 \mathrm{~h}$ (green). The triangle (green on left, blue dashed on right) highlights the region affected by heavy precipitation (cf. Fig. 3a). The red star in $b$ and $d$ indicates the mean position of the WCB trajectories shown in Fig. 6a and b, respectively. (e-h) the same as in Fig. $5 a-d$ except for 2 and 3 June 2013. 
(labelled "F" in Fig. 5a) is located over the Czech Republic and eastern Germany right ahead of a short-wave trough that travelled cyclonically around the upper-level cut-off. "Frederik" had formed over the Balkans two days earlier. A region of low-PV air over Germany, the Alps and northern France is associated with WCB outflow (indicated by the black crosses in Fig. 5a) and reflects southward(!) ridgebuilding that erodes the western part of the cut-off. The WCB had formed in association with the intensification of "Frederik" and causes heavy precipitation over central and eastern Europe (green contour, Fig. 5b). In the core region of the heavy precipitation event (blue triangle) as well as in the WCB outflow region over France, the visible satellite image indicates almost complete cloud coverage (Fig. 5b). The core region is also in the centre of WCB-linked precipitation. A second WCBlinked precipitation region emerges near the Romanian Black Sea coast near $28^{\circ} \mathrm{E}, 48^{\circ} \mathrm{N}$ (Fig. 5b), where cyclone "Günther" ("G", Fig. 5a) develops ahead of a second small-scale trough.

During the next $24 \mathrm{~h}$, "Frederik" crosses the Alps and dissipates over northern Italy (Fig. 5c). The outflow of the associated WCB erodes the western half of the upper-level cutoff over France, Switzerland, northern Italy and the western Mediterranean. Over the Atlantic the blocking anticyclone decayed on 1 June 2013, 00:00 UTC, and the associated surface anticyclone moved north-eastward towards the British Isles. The Scandinavian blocking is maintained and the blocked region extends southward over the Baltic States and north-western Russia. Precipitation associated with WCB activity continues in the core region (Fig. 5d). Over eastern Europe the second WCB-linked precipitation region moved westward along with the westward tracking cyclone "Günther" ("G", Fig. 5c). Thick cloud coverage is evident over Germany, the Alps, the Czech Republic, and Poland (Fig. 5d).

On 2 June 2013, 12:00 UTC, Atlantic blocking reestablishes in a region of upper-level ridgebuilding downstream of a Newfoundland cyclone (Fig. 5e). North and north-west of the European cut-off, low-PV air is evident in the region of the WCB outflow associated with cyclone "Günther". Here the Scandinavian block extends southward to north-eastern Germany and the Baltic Sea. WCB-linked precipitation is now strongest in the eastern half of the core region just west of the centre of "Günther" (Fig. 5f). The area affected by flooding remains completely cloud-covered. The area of WCB-precipitation is almost in the centre of this meridionally elongated cloudy region indicating that these strongly precipitating clouds are linked to WCB ascent.

One day later, very low-PV air is present north of the Alps reflecting a second period of strong southward and westward ridgebuilding (Fig. 5g). WCB intersection points indicate that this ridgebuilding is due to WCB outflow, which strongly erodes the cut-off that repeatedly triggered cyclogenesis and associated WCBs over (south)eastern Europe. The remnant stratospheric PV cut-offs deform into elongated PV filaments and dissipate. Over the Atlantic, the surface anticyclone moves over the British Isles and starts to merge with the Scandinavian anticyclone. Also the Atlantic blocking region extends north-eastward before merging with the Scandinavian blocking during the next days (not shown). Satellite imagery indicates that the core region is still completely covered in clouds (Fig. 5h) and WCB-linked precipitation continues in the northern part of the core region.

In summary, a quasi-stationary cut-off low repeatedly triggered cyclogenesis ahead of short-wave troughs over eastern Europe during the core period of the heavy precipitation event. These cyclones unusually tracked westward into central Europe and are therefore not cyclones of type "Vb". Interestingly the persistent heavy precipitation occurred during the transition from a predominantly Atlantic into a Scandinavian blocking regime. WCB diagnostics showed that repeated slantwise ascent and associated WCB precipitation occurred within these cyclones during the core period of the heavy precipitation event. Likewise WCB trajectory intersection points with the $320 \mathrm{~K}$ isentropic surface revealed that low-PV air in the WCB outflow acted to erode the upperlevel cut-off. As will be discussed in detail in the next section, these WCBs unusually ascended southward, which is opposite to classical WCBs that ascend poleward. We therefore refer to this special type as "equatorward ascending WCBs".

\section{Equatorward ascending warm conveyor belts}

\subsection{Characteristics during the flooding event}

Examples of equatorward ascending WCBs during the event are shown in Fig. 6a, b. Both equatorward ascending WCBs emerge (black starting points and blue colours) from the region of high accumulated rainfall in the previous 15 days (Fig. 1), which coincides with the region of maximum moisture uptake (Fig. 4). Both WCBs also ascend (pale colours) over the core region of the heavy precipitation event, reflecting their crucial role in contributing to the intense precipitation.

In the following the equatorward ascending $\mathrm{WCB}$, starting on 30 June 2013, 12:00 UTC, (Fig. 6a) near $54^{\circ} \mathrm{N}$ from northern Germany and Poland and with an upper-level outflow near $45^{\circ} \mathrm{N}$ over the Balkans two days later, is discussed in more detail. The air parcels follow a southward path and converge over the core region of the heavy precipitation event. Strongest ascent occurs on 31 May 2013, 12:00 UTC, at the northern side of the Alps (near $12^{\circ} \mathrm{E}$, $48^{\circ} \mathrm{N}$, cf. Fig. $5 \mathrm{~b}$ ) reflected in the the sharp transition from blue $(>900 \mathrm{hPa})$ to light red $(<500 \mathrm{hPa})$ colours in Fig. 6a. The outflow (red colours) of this equatorward ascending WCB is directed southward and eastward towards the Black Sea and coincides with the region of low-PV air on $320 \mathrm{~K}$ at the end of the ascent (green contour in Fig. 6a and 
(a) WCB trajectories starting 30/12Z

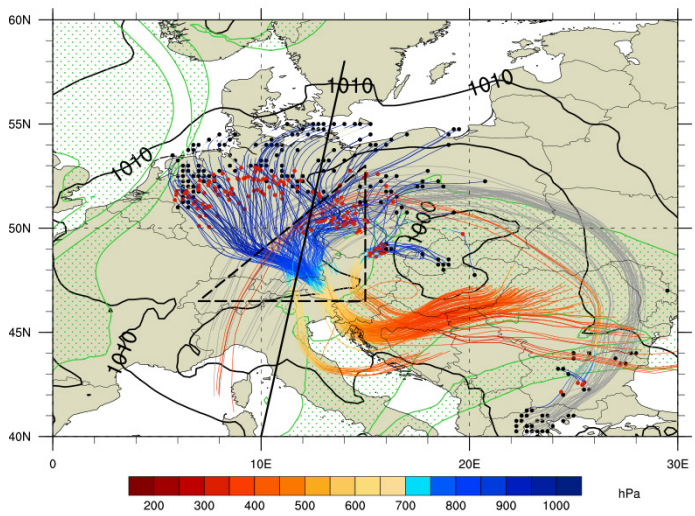

(c) $850 \mathrm{hPa} \Theta_{e} 31 / 00 \mathrm{Z}$

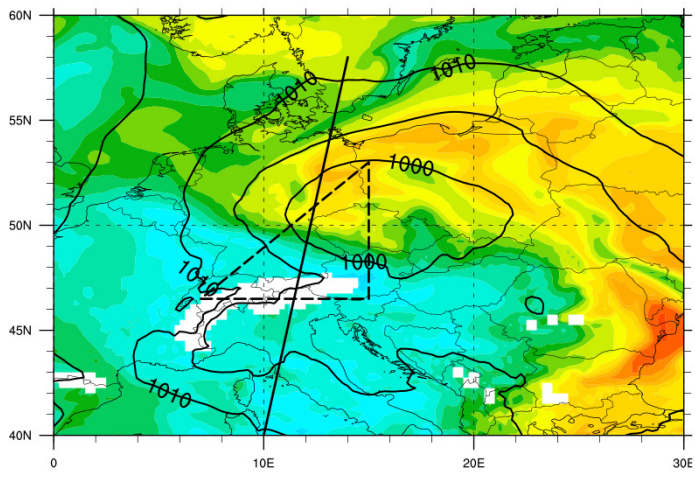

(b) WCB trajectories starting $31 / 12 Z$

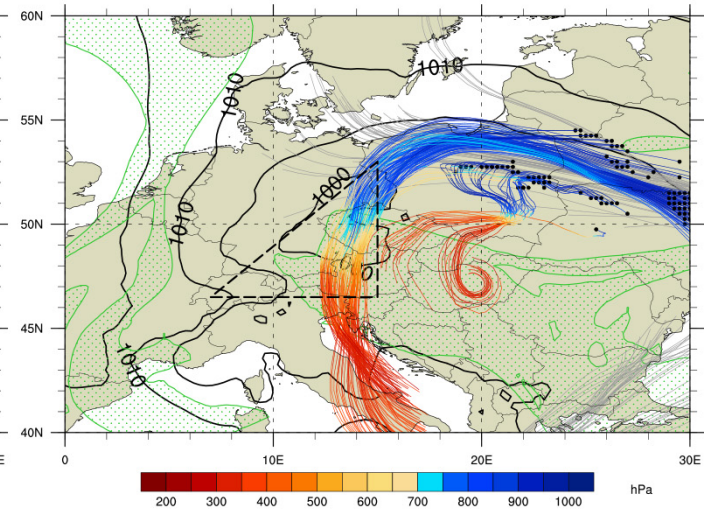

(d) cross section $31 / 00 \mathrm{Z}$

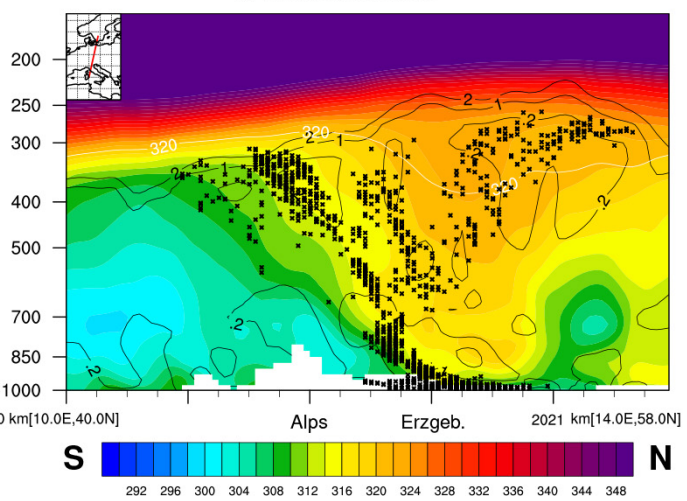

Figure 6. (a): WCB trajectories starting on 30 May 2013, 12:00, and ending on 1 June 2013, 12:00 UTC, sea level pressure (slp) at the WCB starting time (black every $5 \mathrm{hPa}$ ) and PV at $320 \mathrm{~K}$ (green hatched $>2$ PVU) at the WCB end time. Black dots mark the trajectory start locations, red dots the locations of the air parcels after $12 \mathrm{~h}$ (31 May 2013, 00:00 UTC). "Equatorward ascending WCBs" are coloured with pressure (see colour bar). (b): for WCB trajectories starting on, 31 May 2013, 12:00 UTC, and ending on 2 June 2013, 12:00 UTC, and without red dots. (c): $850 \mathrm{hPa} \theta_{\mathrm{e}}$ (shaded every $2 \mathrm{~K}$ as in d) and slp (black, every $5 \mathrm{hPa}$ ) on 31 May 2013, 00:00 UTC. (d): Cross section on 31 May 2013, 00:00 UTC, of $\theta_{\mathrm{e}}$ (shaded every $2 \mathrm{~K}$ as in c), $\theta$ (white contour for $320 \mathrm{~K}$ ), PV (black, $0.2,1.0$, and 2.0 PVU), and every 5th WCB trajectory intersection point. Triangle in (a-c) highlights the region affected by heavy precipitation. Black line in (a) and (c) shows the location of the cross section in (d).

cf. Fig. 5c), confirming that the WCB outflow acts to erode the cut-off.

The equivalent potential temperature $\left(\theta_{\mathrm{e}}\right)$ at $850 \mathrm{hPa}$ reveals a very cool air mass in the region of the upper-level cut-off centred over northern Italy (Fig. 6c). A marked warm front is located over southern Germany and the Czech Republic, with the warm air advected around "Frederik" towards the south-west. This temperature configuration suggests that the equatorward ascending WCB that emerges from the warm-sector ascends along moist isentropes over the cold air pool that stalls north of the Alps. A cross section of $\theta_{\mathrm{e}}$ from the Mediterranean to the Baltic Sea (Fig. 6d) reveals that the baroclinicity with a warmer air mass in the North extends through the entire troposphere. For example the $314 \mathrm{~K}$ moist isentrope slopes upward from the "Erzgebirge" to the Alps. A local $\theta_{\mathrm{e}}$ minimum $\left(\theta_{\mathrm{e}}<305 K\right)$ is trapped north of the Alps. In the lower troposphere between the Erzgebirge and the Alps, the vertical gradient of $\theta_{\mathrm{e}}$ is particularly strong. WCB trajectory intersection points indicate moist-isentropic upgliding in this area near the $314 \mathrm{~K} \theta_{\mathrm{e}^{-}}$ layer. While the intersection points at very low levels north of the Erzgebirge reflect the inflow over Poland and northern Germany, moist isentropic ascent is evident over the Erzgebirge and continues to upper levels over the Alps. Similarly ascent over the Erzgebirge and north of the Alps occurred within WCBs that started during the next days, while their starting region shifted eastward as shown exemplarily in Fig. 6b. Also these later WCBs start over the continent in the region with high accumulated rainfall during the previous 15 days (Figs. 1 and 4 ).

In essence, a reversed temperature gradient extending through the entire troposphere caused the WCBs to ascend southward in the form of equatorward ascending WCBs. Thus the classical definition of a WCB as an airstream ascending rapidly poleward misses important WCBs that share similar physical characteristics and impacts, but occur in a 

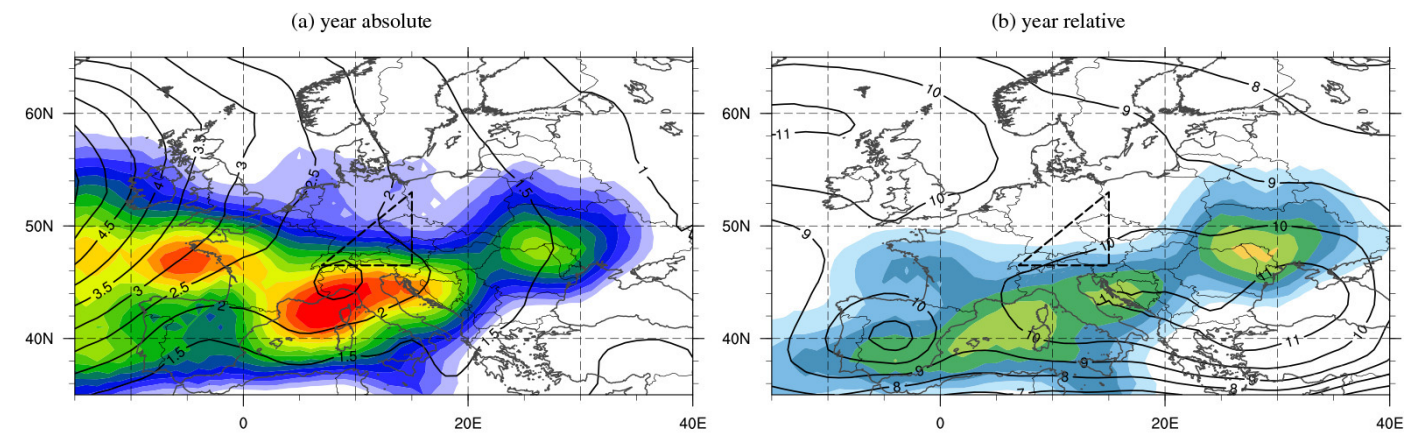

(c) May -June absolute
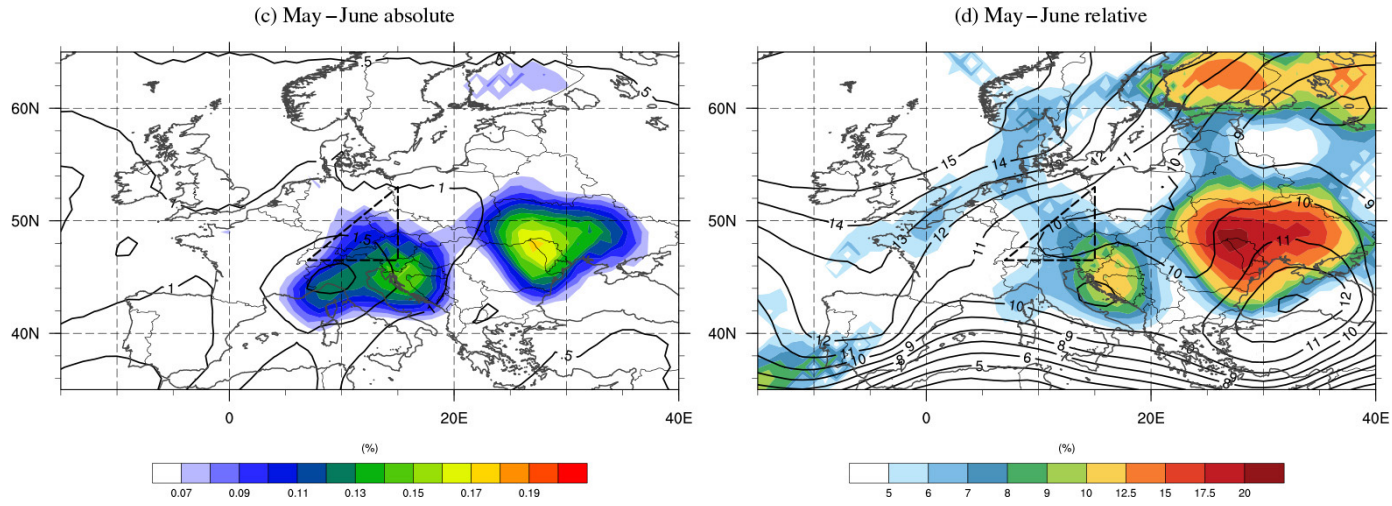

Figure 7. (a, c): frequency of "equatorward ascending WCBs" (shaded every $0.01 \%$ ) and total WCB frequency (contours every $0.5 \%$ ). (b, d) relative frequency of "equatorward ascending WCBs" (shaded in \% see colour bar) and cut-off frequency in the layer 305-330 K (contours every $1.0 \%)$. In (a, b) the climatology for the entire 34 year (1979-2012) ERA-Interim data set is shown. In (c, d) only the climatology for May-June is shown.

strongly anomalous flow setting with equatorward sloping isentropes.

\subsection{Climatology for Europe}

Since this is the first study that explicitly identifies the relevance of equatorward ascending WCBs for heavy precipitation events, the climatological frequency of equatorward ascending WCBs in Europe is briefly investigated. An equatorward ascending WCB is identified from the general ERAInterim (1979-2012) WCB climatology (Madonna et al., 2014) by the criterion that the latitude at the start of the ascent is further poleward compared to the latitude at the end of the ascent. The equatorward ascending WCB frequency is determined as the fraction of 6-hourly ERA-Interim time steps that exhibit at least one equatorward ascending WCB within the vertical column at the respective grid point. Thereby any stage (inflow, ascent, outflow) of the $48 \mathrm{~h} \mathrm{WCB}$ ascent phase is considered. We also investigate frequencies of stratospheric PV cut-offs within the layer spanned by the 305-330 K (every $5 \mathrm{~K}$ ) isentropic surfaces (see Sect. 2.2).

Maximum absolute equatorward ascending WCB frequencies occur near Brittany, southern France, northern Italy, the northern Balkans, and north of the Black Sea while the maximum absolute frequency of all WCB is further to the west over the Atlantic (Fig. 7a). The relative equatorward ascend- ing WCB frequency (the ratio of the absolute equatorward ascending WCB frequency and the absolute WCB frequency) has a clear maximum in a band stretching from the western Mediterranean to north of the Black Sea (Fig. 7b). Here up to $10 \%$ of all WCBs are equatorward ascending WCBs. Interestingly this maximum is collocated with a band of maximum cut-off low frequency stretching from Spain to the Black Sea. In particular in the eastern parts, the band of maximum relative WCB frequency is slightly poleward of the maximum cut-off frequency. This supports our finding that reversed baroclinicity due to the quasi-stationary advection induced by an upper-level cut-off favours WCBs to ascend equatorward.

The climatology of equatorward ascending WCBs during May and June, the season when the flooding occurred, shows a slightly different picture (Fig. 7c, d). Maxima of absolute equatorward ascending WCB frequency are now confined to a region south of the Alps and again north of the Black Sea (Fig. 7c). The total WCB frequency also has a maximum south of the Alps. However next to the maxima in relative equatorward ascending WCB frequency north of the Black Sea and in north-western Russia an important maximum occurs over the Balkans (Fig. 7d) stretching to northern Italy and the core region affected by flooding north of the Alps in early June 2013. Here the relative equatorward ascending 
WCB frequency exceeds $7 \%$. This northern Alpine maximum is again located slightly north of a local cut-off frequency maximum.

Thus although the equatorward ascending WCBs responsible for the heavy precipitation during the early June 2013 flood in central Europe do not occur in a region with maximum climatological frequency they are located in a region where climatological May/June frequencies are increased and cut-off low frequency has a maximum further south. This supports the hypothesis that the reversed baroclinicity associated with RWB and cut-offs is necessary for equatorward ascending WCBs to occur. However, from the absolute numbers it becomes obvious that equatorward ascending WCBs impinging on the northern Alps are very rare events.

\section{Conclusions and outlook}

In this study we explored the meteorological situation that led to a very severe flooding event in central Europe in early June 2013. The two weeks prior to the flooding event were characterised by a predominantly Atlantic blocking regime and rather cool and wet conditions in Europe. An intense cyclonic RWB event over Europe led to the transition of the blocking regime and triggered three consecutive, shallow, and rather short-lived cyclones over eastern Europe. These cyclones tracked westward into central Europe and established a persistent northerly flow against the west-east oriented central European mountain ranges. Due to the cyclonic RWB an upper-level cut-off low and a cool air mass became stationary over the Alps and the western Mediterranean. Within the northerly flow strong large-scale lifting occurred in so-called equatorward ascending WCBs that unusually ascended southward along the reversed strong baroclinicity, resulting in the heavy precipitation that lasted over the same region for several days. A brief climatological analysis for May/June showed that, although relative equatorward ascending WCB frequencies are increased north of the Alps and upper-level cut-off frequencies are increased over the Alps, equatorward ascending WCBs are very rare flow systems in absolute numbers. Nevertheless, they have high potential for triggering very severe heavy precipitation events and represent an important dynamical mechanism for flooding events in the northern Alpine region.

This study has implications for future research in various fields of atmospheric dynamics that are briefly outlined here:

- It is striking that the June 2013 flood occurred at the end of a period characterised by a particular weather regime, suggesting that persistent large-scale atmospheric flow conditions can be key for the occurrence of extreme events. It would be worthwhile investigating how often extreme precipitation events occur at the time of transition between weather regimes, and whether the event itself contributes to this transition.
- In terms of synoptic weather systems, the key finding of this study is that a quasi-persistent upper-level cut-off can instigate a sequence of consecutive cyclones with similar tracks, which then trigger the intense precipitation. This raises the question whether such a clustering of cyclones is typical for European summer season floods and whether cyclone clustering for this type of events differs from the clustering of European winter storms (e.g. Mailier et al., 2006; Pinto et al., 2013).

- The moisture source diagnostic revealed a very high contribution from land evapotranspiration in a region with anomalously wet conditions during the previous two weeks. More cases of extreme precipitation should be analysed to assess the role and variability of continental moisture sources and soil moisture preconditioning.

- The key role of equatorward ascending WCBs for the considered flood event prompts the question on the relevance of these rare airstreams for other extreme precipitation events. Further it would be interesting to investigate if it is a general characteristic of equatorward ascending WCBs to occur in a stationary large-scale flow situation and to persistently ascend in the same region during a prolonged period.

- The identified diabatic PV modification in the equatorward ascending WCBs contributed to the partial erosion of the upper-level cut-off, which can be seen as an intrinsic negative feedback process. The diabatic erosion of upper-level cut-offs has been studied primarily in the context of stratosphere troposphere exchange (e.g. Wirth, 1995; Bourqui, 2006) and RWB (e.g. Morgenstern and Davies, 1999; Grams et al., 2011). It could be interesting to investigate this feedback process also in the context of extreme precipitation events and to test the hypothesis that long-duration heavy precipitation events only occur if the diabatic erosion is comparatively weak and/or the intensity of the upper-level cut-off particularly strong.

Future research on these topics, ranging from large-scale weather regimes to synoptic-scale weather systems and mesoscale interactions between cloud diabatic and dynamical processes, can be useful for further improving our understanding and forecasting capability of mid-latitude highimpact weather events.

Acknowledgements. This project was supported by the German Research Foundation (DFG) as part of the research unit PANDOWAE (FOR896), the Swiss Federal Office for the Environment (project "Starkniederschläge und Hochwasser"), and the Swiss National Science Foundation (SNSF, project 200020_146834). We thank MeteoSuisse and ECMWF for enabling access to ECMWF data. Furthermore, we acknowledge Eumetsat and the Dundee Satellite 
Receiving Station for providing high-resolution Meteosat satellite imagery via their webpage http://www.sat.dundee.ac.uk. We thank Michael Sprenger (IAC, ETHZ) for help with plotting the satellite imagery, Maxi Böttcher (IAC, ETHZ) for providing plotting tools, and Kirstin Schamm (DWD) for discussing the GPCC data. Further we are grateful to Erica Madonna, Bojan Škerlak, Harald Sodemann (IAC, ETHZ), and Olivia Martius (GIUB, Uni Bern) for help with diagnostics.

Edited by: G. Panegrossi

Reviewed by: two anonymous referees

\section{References}

Altenhoff, A. M., Martius, O., Croci-Maspoli, M., Schwierz, C., and Davies, H. C.: Linkage of atmospheric blocks and synopticscale Rossby waves: a climatological analysis, Tellus Series A, 60, 1053-1063, doi:10.1111/j.1600-0870.2008.00354.x, 2008.

Bourqui, M. S.: Stratosphere-troposphere exchange from the Lagrangian perspective: a case study and method sensitivities, Atmos. Chem. Phys., 6, 2651-2670, doi:10.5194/acp-6-2651-2006, 2006.

Browning, K. A.: Organization of clouds and precipitation in extratropical cyclones, in: The Erik Palmen Memorial Volume, edited by: Newton, C. and Holopainen, E., 129-153, American Meteorological Society, 1990.

Browning, K. A., Hardman, M. E., Harrold, T. E., and Pardoe, C. W.: The structure of rainbands within a midlatitude depression, Q. J. Roy. Meteorol. Soc., 99, 215-231, doi:10.1002/qj.49709942002, 1973.

Croci-Maspoli, M., Schwierz, C., and Davies, H. C.: A multifaceted climatology of atmospheric blocking and its recent linear trend, J. Climate, 20, 633-649, doi:10.1175/JCLI4029.1, 2007.

Dee, D. P., Uppala, S. M., Simmons, A. J., Berrisford, P., Poli, P., Kobayashi, S., Andrae, U., Balmaseda, M. A., Balsamo, G., Bauer, P., Bechtold, P., Beljaars, A. C. M., van de Berg, L., Bidlot, J., Bormann, N., Delsol, C., Dragani, R., Fuentes, M., Geer, A. J., Haimberger, L., Healy, S. B., Hersbach, H., Hólm, E. V., Isaksen, L., Kållberg, P., Köhler, M., Matricardi, M., McNally, A. P., Monge-Sanz, B. M., Morcrette, J.-J., Park, B.-K., Peubey, C., de Rosnay, P., Tavolato, C., Thépaut, J.-N., and Vitart, F.: The ERA-Interim reanalysis: configuration and performance of the data assimilation system, Q. J. Roy. Meteorol. Soc., 137, 553597, doi:10.1002/qj.828, 2011.

Grams, C. M., Wernli, H., Böttcher, M., Čampa, J., Corsmeier, U., Jones, S. C., Keller, J. H., Lenz, C.-J., and Wiegand, L.: The key role of diabatic processes in modifying the upper-level tropospheric wave guide: a North Atlantic case study, Q. J. Roy. Meteorol. Soc., 137, 2174-2193, doi:10.1002/qj.891, 2011.

Hohenegger, C., Walser, A., Langhans, W., and Schär, C.: Cloudresolving ensemble simulations of the August 2005 Alpine flood, Q. J. Roy. Meteorol. Soc., 134, 889-904, doi:10.1002/qj.252, 2008.

Hoskins, B. J., McIntyre, M. E., and Robertson, A. W.: On the use and significance of isentropic potential vorticity maps, Q. J. Roy. Meteorol. Soc., 111, 877-946, doi:10.1002/qj.49711147002, 1985.
James, P., Stohl, A., Spichtinger, N., Eckhardt, S., and Forster, C.: Climatological aspects of the extreme European rainfall of $\mathrm{Au}-$ gust 2002 and a trajectory method for estimating the associated evaporative source regions, Nat. Hazards Earth Syst. Sci., 4, 733 746, doi:10.5194/nhess-4-733-2004, 2004.

Keil, C., Volkert, H., and Majewski, D.: The Oder flood in July 1997: Transport routes of precipitable water diagnosed with an operational forecast model, Geophys. Res. Lett., 26, 235-238, 1999.

LfU: Junihochwasser $2013 \quad$ - Wasserwirtschaftlicher Bericht, http://www.hnd.bayern.de/ereignisse/hw062013/ Junihochwasser2013_2013-10-17.pdf (last access: 4 November 2013), 2013.

Madonna, E., Wernli, H., Joos, H., and Martius, O.: Warm conveyor belts in the ERA-Interim data set (1979-2010). Part I: Climatology and potential vorticity evolution, J. Climate, 27, 3-26, doi:doi:10.1175/JCLI-D-12-00720.1, 2014.

Mailier, P. J., Stephenson, D. B., Ferro, C. A. T., and Hodges, K. I.: Serial clustering of extratropical cyclones, Mon. Weather Rev., 134, 2224-2240, doi:10.1175/MWR3160.1, 2006.

Massacand, A. C., Wernli, H., and Davies, H. C.: Heavy precipitation on the alpine southside: An upper-level precursor, Geophys Res. Lett., 25, 1435-1438, doi:10.1029/98GL50869, 1998.

Michel, C. and Rivière, G.: The Link between Rossby Wave Breakings and Weather Regime Transitions, J. Atmos. Sci., 68, 17301748, doi:10.1175/2011JAS3635.1, 2011.

Michel, C., Rivière, G., Terray, L., and Joly, B.: The dynamical link between surface cyclones, upper-tropospheric Rossby wave breaking and the life cycle of the Scandinavian blocking, Geophys. Res. Lett., 39, L10806, doi:10.1029/2012GL051682, 2012.

Morgenstern, O. and Davies, H. C.: Disruption of an upper-level PV-streamer by orographic and cloud-diabatic effects, Contributions to Atmospheric Physics, 72, 173-186, 1999.

Munich RE: Floods dominate natural catastrophe statistics in first half of 2013, press Release 9 July 2013 http://www.munichre.com/en/media_relations/press_releases/ 2013/2013_07_09_press_release.aspx (last access: 4 November 2013), 2013.

Pfahl, S. and Wernli, H.: Quantifying the relevance of atmospheric blocking for co-located temperature extremes in the Northern Hemisphere on (sub-)daily time scales, Geophys. Res. Lett., 39, L12807, doi:10.1029/2012GL052261, 2012a.

Pfahl, S. and Wernli, H.: Quantifying the relevance of cyclones for precipitation extremes, J. Climate, 25, 6770-6780, doi:10.1175/JCLI-D-11-00705.1, 2012b.

Pfahl, S., Madonna, E., Boettcher, M., Joos, H., and Wernli, H.: Warm conveyor belts in the ERA-Interim data set (1979-2010). Part II: Moisture origin and relevance for precipitation, J. Climate, 27, 27-40, doi:10.1175/JCLI-D-13-00223.1, 2014.

Pinto, J. G., Bellenbaum, N., Karremann, M. K., and DellaMarta, P. M.: Serial clustering of extratropical cyclones over the North Atlantic and Europe under recent and future climate conditions, J. Geophys. Res.- Atmos., 118, 12476-12485, doi:10.1002/2013JD020564, 2013.

Schamm, K., Ziese, M., Becker, A., Finger, P., Meyer-Christoffer, A., Schneider, U., Schröder, M., and Stender, P.: Global gridded precipitation over land: a description of the new GPCC First Guess Daily product, Earth Syst. Sci. Data, 6, 49-60, doi:10.5194/essd-6-49-2014, 2014. 
Schneider, U., Becker, A., Finger, P., Meyer-Christoffer, A., Ziese, M., and Rudolf, B.: GPCC's new land surface precipitation climatology based on quality-controlled in situ data and its role in quantifying the global water cycle, Theor. Appl. Climatol., 115, 15-40, doi:10.1007/s00704-013-0860-x, 2014.

Schwierz, C., Croci-Maspoli, M., and Davies, H. C.: Perspicacious indicators of atmospheric blocking, Geophys. Res. Lett., 31, L06125, doi:10.1029/2003GL019341, 2004.

Sodemann, H. and Zubler, E.: Seasonal and inter-annual variability of the moisture sources for Alpine precipitation during 19952002, Int. J. Climatol., 30, 947-961, doi:10.1002/joc.1932, 2010.

Sodemann, H., Schwierz, C., and Wernli, H.: Interannual variability of Greenland winter precipitation sources: Lagrangian moisture diagnostic and North Atlantic Oscillation influence, J. Geophys. Res., 113, D03107, doi:10.1029/2007JD008503, 2008.

Sodemann, H., Wernli, H., and Schwierz, C.: Sources of water vapour contributing to the Elbe flood in August 2002 - A tagging study in a mesoscale model, Q. J. Roy. Meteorol. Soc., 135, 205-223, doi:10.1002/qj.374, 2009.

Stohl, A. and James, P.: A Lagrangian analysis of the atmospheric branch of the global water cycle. Part I: method description, validation, and demonstration for the August 2002 flooding in Central Europe, J. Hydrometeorol., 5, 656-678, doi:10.1175/15257541(2004)005<0656:ALAOTA>2.0.CO;2, 2004.

Ulbrich, U., Brücher, T., Fink, A. H., Leckebusch, G. C., Krüger, A., and Pinto, J. G.: The central European floods of August 2002: Part 1 - Rainfall periods and flood development, Weather, 58, 371-377, 2003a.

Ulbrich, U., Brücher, T., Fink, A. H., Leckebusch, G. C., Krüger, A., and Pinto, J. G.: The central European floods of August 2002: Part 2 - Synoptic causes and considerations with respect to climatic change, Weather, 58, 434-442, 2003b.

van Bebber, W. J.: Die Zugstrasse der barometrischen Minima nach den Bahnenkarten der Deutschen Seewarte von 1887-1890, Meteorol. Z., 8, 361-366, 1891.
Vautard, R.: Multiple weather regimes over the North Atlantic: analysis of precursors and successors, Mon. Weather Rev., 118, 2056-2081, doi:10.1175/15200493(1990)118<2056:MWROTN>2.0.CO;2, 1990.

Wernli, H. and Davies, H. C.: A Lagrangian-based analysis of extratropical cyclones. I: The method and some applications, Q J. Roy. Meteorol. Soc., 123, 467-489, doi:10.1256/smsqj.53810, 1997.

Wernli, H. and Sprenger, M.: Identification and ERA-15 climatology of potential vorticity streamers and cutoffs near the extratropical tropopause, J. Atmos. Sci., 64, 1569-1586, doi:10.1175/JAS3912.1, 2007.

Winschall, A.: Evaporative moisture sources for heavy precipitation events, Ph.D. thesis, ETH Zurich, Switzerland, doi:10.3929/ethza-009755505, 2013.

Winschall, A., Pfahl, S., Sodemann, H., and Wernli, H.: Impact of North Atlantic evaporation hot spots on southern Alpine heavy precipitation events, Q. J. Roy. Meteorol. Soc., 138, 1245-1258, doi:10.1002/qj.987, 2012.

Winschall, A., Pfahl, S., Sodemann, H., and Wernli, H.: Comparison of Eulerian and Lagrangian moisture source diagnostics the flood event in eastern Europe in May 2010, Atmos. Chem. Phys., 14, 6605-6619, doi:10.5194/acp-14-6605-2014, 2014.

Wirth, V.: Diabatic heating in an axisymmetric cut-off cyclone and related stratosphere-troposphere exchange, Q. J. Roy. Meteorol. Soc., 121, 127-147, doi:10.1002/qj.49712152107, 1995.

Zängl, G.: Interaction between dynamics and cloud microphysics in orographics precipitation enhancement: a high-resolution modeling study of two north Alpine heavy precipitation events, Mon. Weather Rev., 135, 2817-2840, 2007a.

Zängl, G.: To what extent does increased model resolution improve simulated precipitation fields? A case study of two north-Alpine heavy-rainfall events, Meteorologische Z., 16, 571-580, $2007 \mathrm{~b}$. 